\title{
VIHANG A. NAIK - A STUDY OF HIS MIND AND ART
}

\section{SAIFIL ALI MOHAMED ISMAIL}

Associate Professor, Faculty of Business Administration, St.Theresa International College (Deemed University),

Ongkharak Town, Near Bangkok City, Nakhon Nayok Province, Kingdom of Thailand

\section{ABSTRACT}

This publication is a collection of review articles by scholars and writers on the poetry contributions of Vihan A. Naik, an acclaimed Indian English poet and a legendary in linguistics of the 20th century. The authors' views and opinions presented in this book would enlighten the readers' understanding about the legendary poet.

KEYWORDS: Poet, Linguistics \& Readers

Received: Sep 21 2018; Accepted: Oct 11, 2018; Published: Nov 30, 2018; Paper Id.: IJHRDEC20183

\section{INTRODUCTION}

The author of this book, Dr.Sanjay Prasad Pandey, a doctorate from VBS Purvanchal University, Jaunpur, Uttar Pradesh is an Assistant professor of English at Lovely professional University, Punjab, India and is actively involved in teaching and research for 15 years. He has authored a book titled 'The Treatment of Women in Shashi Deshpande's Novels', and edited a book titled 'Thinking out of the Box'. His articles and research papers have been published in different national and international journals.

The author has made an attempt to look at the mind and heart of Vihang A.Naik, with a fresh perspective, consciously based on the review comments of authors, writers and critics on his poetry contributions. The author has quoted the contributions of scholars, critics and writers liberally in the entire text of this book, and few papers and interview discussions have been presented elsewhere in his edited journal, 'The Achievers Journal'.

\section{SUMMARY OF CONTENT}

The book presents fifteen articles in the form of review work by different scholars and writers. The first article 'Vihang A.Naik: A Study of his Mind and Art' carries the author's highlights on the history, characteristics and contributions of Vihang A. Naik to English poetry and Indian literature. The second article, 'Illusion and Allusion: A Critical Insight of Vihang A.Naik's “Mirrored Men” by Dr.Sajad Ahmed Ganie explores the creative writing of Vihang on 'mirrored men', a collection of poetry in city times and other poems. The third article 'Death, Disability and Disillusionment in Vihang A. Naik's City Times and Other Poems' by Loveleen Kaur presents how Vihang mirrors the men and manner of the city in a lucid manner. The fourth article by Rohith Chatrath reviews on 'Do not Tower rainbow with Reason: A Critical Study' presents the thematic concerns, philosophical dictates and the literary beauty in the poem. The fifth article of Meena Sharma on 'The Philosophy of Life in "Poet as a Young Man” by Vihang A.Naik explains the poetic analysis, founded over the philosophical pedestal of Vihan A. Naik's poems. The sixth article by S.Noyingbeni Yanthan reviews the poem 'Juxtaposition of Fair and Foul in "Love Song of a Journeyman' by Vihang A.Naik, which presents the experience of disloyalty of love. The seventh article by Tobi Ete critically analyses the love, lust and lure elements in the poem 'Love song of a journeyman' of Vihang 
A.Naik. The eighth article by Rituparna Datta Roy on 'Influence of Classical Greek Mythology and English poets on Vihang A. Naik: A study on selected poems' presents her reading experience of the poems. Ms. Parminder Sohal in the ninth article, 'Did Vihang A.Naik Unlock his Heart with the Key "The Path of wisdom"? views an aura of fresh life in the poems. The tenth article, 'A Representation of Unsuccessful Love in "Love Song of a Journeyman” by Meenakshi Rana presents how Vihang explains about lover's journey of love through his emotions and feelings. The eleventh article, 'Life of a City in all its Shades: An Analysis of Vihang A.Naik's Poetry' by Rakesh Kumar presents how Vihang shows his utter disgust for city life. The twelfth article by Brij Mohan and Pawan Kumar is on 'Degradation of Moral and Ethical Values: A Study of Vihang A.Naik's Poetry Manifesto: New and Selected Poems'. The thirteenth article on 'Tantalising Glimpses and Darker Psyche Portrayal in Vihang A.Naik's “The Love Song of Journey Man" explores the concept and consequences of unrequited love and its depth. In the Poetry Manifesto book review, the fourteenth article, the author Dr.S.N.Singh appreciates the poet's blossoming quality quantum quest. The fifteenth article by the author of this book is a 'Book talk' on Vihang Naik's City Times and Other Poems.

\section{ANALYSIS AND EVALUATION}

Articles in the beginning part of the book analyse the various writings of Vihang A.Naik in Gujarati and English, and appreciates his natural and skilful usage of English in expressing emotions, feelings, his reminiscences, love and experiences, frustrations and disillusionments in all his poems. The authors express the ability of Vihang A.Naik in thematically presenting all aspects of contemporary life in diversified India, in his poetic collections. It has been acclaimed by the author that Vihang A.Naik is a contemporary bilingual poet, who writes authentic poems rather than imaginary. His poems have been compared with those of classical Greek mythology. Vihang A.Naik is identified by the authors as the person, who wants a breath of fresh air, and to breathe a tension free life. He is typically gifted and talked about writer, and the one who gives courage to the world to attain success and not give up hope.

Articles in the middle part of the book presents that, a focus on the psychic disability caused by unrequited love in the course or fulfillment perusal has been made in the poems of Vihang A.Naik, and it is found that he spells out the impact of unrequited love on success of love and the kind of pain an unsuccessful love pass through one's life. Writers have identified the urban angst, conspicuously very high in his poems. Nevertheless, five poems of Vihang deal with the moral and ethical degradation of youth that emerge as cultural problem in India.

However, articles in the concluding part of the book question Vihang's poetic appeal. As put forth by Dr.Singh, Vihan A.Naik treasures the poet's quality quantum quest under its blossom, which is widely ranging from the quest of his own self-realisation, introspection, observations of mind and soul, man-nature relationship, man-nature disconnect, impact of society on human beings and finally the cyber society. However he states, the quest of genuine nature poet initiating from From Making a Poem (page.92) remains inconclusive, and his emotional appeal has been questioned. Further, it has been criticized that his poems open eyes to the city only and, in his Poetry manifesto: New and Selected Poems, he has been criticized for opening avenues inviting critical aggressiveness and rash attacking remarks by making a choice of preferring philosophy and sacrificing aesthetics, ruthlessly (page.93). And, a glimpse of antithetical poetic world of Naik, as experienced by his counterparts; Gautam Karmakar, Gargi Biswas and Shashikant Nishant Sharma are presented.

The author, Dr.Sanjay Prasad Pandey has presented his own analysis and comments on the poetic contributions of Vihan A.Naik, as reflections of his mind and artistic manifestations. The strength and courage giving presentations of 
Vihang in the poems give invaluable lessons for the readers to have courage and retain dignity, at all times.

\section{CONCLUSIONS}

The collection of reviews on poems in the form of book is an outstanding peace for taking genius and legendary writers to the hearts of people. This book, in general, is a compilation of fourteen review articles by different scholars and writers including the author on Vihang A.Naik, a widely acclaimed Indian English poet, critic and editor from south Gujarat. Although this publication talks little about the shortcomings in the poems as perceived by the critics, with the acknowledged merits, the author acclaims Vihang A.Naik as a celebrated poet in post-modern Indian English poetry. Further, with strong Indian poetic sensibility, awareness of Indian culture and variegated landscape, representation of Indian consciousness and psyche, Vihang A.Naik has been established by the author as well as contributors of this publication, as a great Indian English poet, with unique and unsurpassable position.

\section{Book Review}

The book titled, "Vihang A. Naik - A Study of His Mind and Art", authored by Dr.Sanjay Prasad Pandey; published by the Authors Press, Q-2A, Hauz Khas Enclave, New Delhi - 110016 (India); the first edition (2018) has been reviewed. The publication has the ISBN 978-93-87651-44-9, printed with 102 pages and priced at INR 400 (\$25).

\section{REFERENCES}

1. Arolia, Jitendra. "Kaleidoscopic Vision in the VihangNaik's Poetry: Manifesto." Research Scholar: An International Refereed e-Journal of Literary Explorations I. II (2013): 1-4. Print.

2. Arora, Sudhir K. "Reflective and Aesthetic Landscapes: The Poetry of Vihang A. Naik." Indian Writing in English: Critical Insights. Ed. Singh, Bijender. New Delhi: Authorspress, 2014. 77-88. Print.

3. Bhaskar, JhaBhaskaranand. "Vihan A Naik's City Times and Other Poems." Boloji.com. Web. Accessed on 14/04/2016 . "Vihang A Naik's Poetry Manifesto: Manifestation of Manifold Musings.” Web. Accessed on 15/04/2016 Biswas, Gargi.

4. "A Dawn of Destruction Reflected in the Poetry of Vihang A. Naik." International Journal of English Research. 2.1. (2016): 04-07. Psychoanalytic Study of Vihang A. Naik's Poetry Manifesto (New and Selected Poems). Research Front. 3.4. (2015): 21-26.

5. Dixit, Kalyani. "Colossal Range of Experiences and Philosophical Vision of Vihang A. Naik in Poetry Manifesto (New and Selected Poems)." Research Scholar: An International Refereed eJournal of Literary Explorations I. IV (2013): 248-252.

6. Naik, Vihang A. Interview with NabanitaDhar. Isahitya. 2011. Print.

7. Patva, Durga. "Poetry of Vihang A. Naik: A Study of Poetic Creation and Theme of Multi-Aspects of Contemporary Life." International Journal of Social Science and Humanities Research. IV.I. (2016): 451-458.

8. Sarangi, Jaydeep. “Jaydeep Sarangi in Conversation with VihangNaik.” Ed. Jha, Vivekanand. VerbalArt: A Global Journal Devoted to Poets and Poetry. 1.2. (2015): 98-106.

9. Sheikh, Shamenaz. "Vihang A. Naik's Poetry Manifesto. Boloji.com 7 Dec. 2012. Web. Accessed on 15/04/2016.

10. Naik, Vihang A. "City Times Other Poems. Bloomington USA: Authorhouse, 3 May 2014. English

11. Nishant Sharma, Shashikant. "Social Realism in Poetry and VihangNaik", International Journal of Research, vol.4.6., May 2017. Print. 
